\title{
ZJAWISKO TARGUMIZMU W ARAMEJSKIEJ WERSJI PIERWSZEJ I DRUGIEJ KSIĘGI KRONIK
}

Głównym zadaniem aramejskich przekładów biblijnych było odpowiednie oddanie tekstu hebrajskiego w języku aramejskim, spowodowane postępującym rozpowszechnianiem się tego języka wśród Żydów. Jednak rola tłumacza - targumisty (meturgemana) nie ograniczyła się tylko do przekładu tekstu oryginalnego, lecz polegała też na objaśnianiu go z wykorzystaniem elementów egzegezy żydowskiej. W targumach tekst święty był uzupełniany, rozszerzany przez tłumacza, który, korzystając z różnych technik adaptacji i aktualizacji, starał się dostosować go do możliwości recepcyjnych aktualnych odbiorców oraz potrzeb wspólnoty. Ten proces, wpisuje się w zjawisko targumizmu czy też targumizacji. W kontekście badań nad Targumem Pieśni nad Pieśniami została podjęta próba doprecyzowania obu pojęć. ${ }^{1}$ Według W. Chrostowskiego należy rozróżnić oba te zjawiska. O ile zjawisko targumizmu dotyczyło głównie oddania tekstu hebrajskiego na język aramejski, to targumizacja obejmuje kompleksowy długotrwały proces powstawania targumów wykorzystujących istniejące już targumy i zawarte w nich różnorodne zmiany językowe, kulturowe i religijne, które znalazły wyraz w wielorakich tendencjach interpretacyjnych. ${ }^{2}$

1 Zjawisko to opisał w języku polskim M. B a r a n i a k, Zjawisko targumizacji na podstawie Targumu do Pieśni nad Pieśniami. Krytyczna edycja tekstu z manuskryptu M 1106 z analiza egzegetyczno-hermeneutyczna i thumaczeniem, Dom Wydawniczy ELIPSA, Warszawa 2013.

2 W. C h ro s tow s k i, M. Baraniak, „Zjawisko targumizacji na podstawie Targumu do Pieśni nad Pieśniami. Krytyczna edycja tekstu z manuskryptu M 1106 
W odniesieniu do aramejskiego przekładu Księgi Kronik zostaną postawione pytania: W jakim środowisku powstały targumy do tych ksiąg i jaki wpływ mogło to mieć na ich przesłanie? W odróżnieniu od innych targumów, nad których tłumaczeniami na język polski podjęto już prace (Targum Neofiti, Targum Jonatana), ${ }^{3}$ czy też badania nad aramejskimi wersjami, np. Targumu Pięcioksięgu, ${ }^{4}$ Targumu Jonatana do ksiąg prorockich ${ }^{5}$ czy też najbardziej popularnego Targumu Pieśni nad Pieśniami ${ }^{6}$ oraz Targum Rut, ${ }^{7}$ które należą do zbioru Targumów

z analiza egzegetyczno-hermeneutyczna i thumaczeniem”, Dom Wydawniczy ELIPSA, Warszawa 2013 (rec.), Collectanea Theologica 83(2013) nr 4, s. 232-238.

3 M. W ró b e 1 (tłum. i oprac.), Biblia Aramejska. Targum Neofiti 1. Ksiega Rodzaju, t. 1, Wydawnictwo Gaudium, Lublin 2014; t e n ż e, Biblia Aramejska Targum Neofiti 1. Ksiega Wyjścia, t. 2. Wydawnictwo Gaudium, Lublin 2017; A. K u ś m i r e k, M. P a r c h e m (tłum. i oprac.), Targum Jonatana. Edycja tekstu aramejskiego, przekład na język polski z wprowadzeniem i notami, t. 1-2, Wydawnictwo Naukowe UKSW, Warszawa 2020 (w przygotowaniu).

4 Np. artykuły na temat interpretacji Księgi Rodzaju w targumach zob. A. K u ś m i r e k, Ksiega Rodzaju 1-11 w targumach palestyńskich, Collectanea Theologica 83(2017) nr 4, s. 75-104; t a ż, Blogosławieństwo Jakuba (Rdz 49,1-28) w interpretacji targumicznej, Collectanea Theologica 88(2018) nr 3, s. 163-190.

5 Np. ta ż, Księga Nahuma w tradycji targumiczne”, Collectanea Theologica 81 (2011) nr 3, s. 101-120 oraz np. t a ż, Aramejska wersja Księgi Amosa, Collectanea Theologica 85(2015) nr 4, s. 177-195.

6 Zob. np. K. B a r d s k i, Świątynia Salomona $w$ Targumie do Pieśni nad Pieśniami 3,7 - 5,1, Collectanea Theologica 2/2000, s. 79-92; t e n ż e, Niewola babilońska $w$ interpretacji Targumu do Pieśni nad Pieśniami 5,2 - 6,17, Studia Lovicensia 3/2001, s. 25-39; t e n ż e, Eschatologia mesjańska w Targumie do Pieśni nad Pieśniami 7,12 - 8,14, w: W. C h r o s t o w s k i (red.), Duch i Oblubienica mówią: „Przyjdz’. Księga Pamiątkowa dla Ojca Profesora Augustyna Jankowskiego OSB w 85. rocznice urodzin, Vocatio, Warszawa 2001, s. 47-58. Poza już wymienioną monografią na temat Tg PnP, zob. M. B a r a n i a k, Motyw miasta w Księdze Pieśni nad Pieśniami i jego targumiczna interpretacja, Scriptura Biblica et Orientalia 3/2011, s. 209-233.

A. K u ś m i r e k, Twój naród będzie moim narodem, twój Bóg będzie moim Bogiem - wyznanie Rut w intepretacji targumu (Rt 1,16-17). w: W. L i n k e (red.), Trud w Panu nie jest daremny (por. 1Kor 15,58). Studia ofiarowane Księdzu Profesorowi Doktorowi Habilitowanemu Janowi Zatęskiemu w 70. rocznicę urodzin, Wydawnictwo Ojców Franciszkanów, Niepokalanów 2010, s. 309-324. 
Pism, na temat Targumu Kronik nie powstały żadne opracowania. Celem tego artykułu jest przedstawienia głównych technik translatorskich i elementów egzegezy żydowskiej obecnych w aramejskiej wersji Księgi Kronik. W świetle przedstawionej dyskusji na temat zjawiska targumizmu i targumizacji w artykule tym przyjmuje się, że targumizacja jest integralnym elementem zjawiska targumizmu.

\section{Status Pierwszej i Drugiej Księgi Kronik w judaizmie}

Pierwsza i Druga Kronik oraz ich przekład aramejski nie należały do ksiąg popularnych, zarówno w czasach starożytnych, jak i nowożytnych. W Biblii Hebrajskiej obie księgi stanowią nierozerwalną całość i noszą hebrajską nazwę dibrê hayyamîm (dosł. „słowa dni”, „wydarzenia czasów”), która wynika z treści księgi. Obejmuje ona historię Izraela od Adama po dekret Cyrusa (538 r.) i czasy odbudowy po wygnaniu. W Septuagincie Kroniki noszą tytuł Paraleipomenōn tōn basileōn Iouda (dosł. „rzeczy opuszczone królów Judy”), są podzielone na dwie części ${ }^{8}$ i zostały umieszczone zaraz po Księgach Królewskich. Nazwa „Kroniki” pochodzi od św. Hieronima., który zatytułował je Chronicon totius divinae historiae (Kroniki całej świętej historii). ${ }^{9}$ Już tytuł z LXX może sugerować, że Kroniki od początku były marginalizowane i uznawane raczej za suplement do Ksiąg Samuela i Królewskich. ${ }^{10}$ Treść tych ksiąg obejmuje historię starożytnego Izraela, poczynając od Adama aż po odbudowę Judy po okresie wygnania babilońskiego.

8 W BH podział przyjęto w XV w.; por. R. W. K l e i n, Chronicles, Book of 1-2, w: D.N. Fre e d m a n (red.), The Anchor Yale Bible Dictionary, t. 1, Doubleday, New York 1992, s. 992.

9 V.P. Ha m ilt o n, Handbook on the Historical Books, Baker Academic, Grand Rapids (MI) 2001, s. 477.

10 M.J. S e $1 \mathrm{~m}$ a n, 1 Chronicles: An Introduction and Commentary, X, Tyndale Old Testament Commentaries, InterVarsity Press, Downers Grove (IL) 1994, s. 20. 
W kanonie Biblii Hebrajskiej Księgi Kronik należą do trzeciego zbioru ksiąg, zwanego Pismami (hebr. kétûtbîm). ${ }^{11}$ Mimo że przedstawia ona szczegóły wydarzeń jeszcze z czasów Ezdrasza i Nehemiasza, to jednak w traktacie talmudycznym Baba Bathra (b. B. B. 14b) została wymieniona po Księdze Ezdradsa i Księdze Nehemiasza, na samym końcu listy Pism.

Według tradycji żydowskiej autorem części księgi jest Ezdrasz: „Ezdrasz napisał księgę, która nosi jego imię, oraz genealogie Kronik sięgające aż do jego czasów" (b. B. B. 15a), nieco dalej w tym samym traktacie jest mowa, że pozostałą część dokończył Nehemiasz.

W odróżnieniu od zbioru Pięciu Zwojów (Hāmēěs Měgillôt), które z czasem przyporządkowano poszczególnym świętom żydowskim, ${ }^{12}$ a zatem były odczytywane w synagodze, Księgi Kronik nie były związane z żadnym świętem ani liturgią synagogalną. Jednak w Misznie można odnaleźć pewne wzmianki na temat odczytywania Kronik. ${ }^{13}$ Chodzi tu o informację, że fragmenty Kronik (tak samo jak Ksiąg: Ezdrasza, Hiob i Daniela) czytano arcykapłanowi, który

11 W skład tego zbioru wchodzą: Księgi: Psalmów, Przysłów, Hioba, Pieśń and Pieśniami, Rut, Lamentacji, Koheleta, Estery, Daniela, Ezdrasza-Nehemiasza i właśnie Kronik. Natomiast w dwóch najważniejszych manuskryptach, to jest Kodeksie Petropolitanus (B19A), datowanym na IX w., i Kodeksie Aleppensis (A), datowanym na X w., po zbiorze Proroków Księgi Kronik znajdują się są na pierwszym miejscu, a po nich dopiero Księgi: Psalmów, Hioba, Przysłów, Rut, Pieśń nad Pieśniami, Koheleta, Lamentacji, Estery, Daniela i Ezdrasza-Nehemiasza. Mogło to wynikać z tego, że skoro postać Dawida odgrywa w niej tak istotną rolę, to stanowi ona dobre wprowadzenie do księgi, której autorstwo przypisuje się właśnie jemu. Zob. J.A. S a n d e r s, Canon: Hebrew Bible, w: D.N. F r e e d m a n (red.), The Anchor Yale Bible Dictionary, t. 1, Doubleday, New York 1992, s. 840.

12 Pieśń nad Pieśniami (Pascha), Księga Rut (Szawuot), Lamentcje (9 Aw), Księga Koheleta (Sukkot) i Księga Estery (Purim). Tradycja przypisująca te księgi do świąt sięga co najmniej VI w., choć niewykluczone, że jej pierwsze przejawy miały miejsce już wcześniej.

13 Zob. I. K a 1 i m i, History of Interpretation: The Book of Chronicles in Jewish Tradition from Daniel to Spinoza, RB 105/1998, s. 5-41; zob. t e n ż e, The Retelling of Chronicles in Jewish Tradition and Literature: A Historical Journey, Eisenbrauns Winona Lake (IN) 2009, s. 141-154. 
nie był biegły w czytaniu Pism. Miało mu to pomóc, aby nie zasnął przed rozpoczęciem obrzędów Dnia Przebłagania (m. Yoma 1,6). ${ }^{14}$ Mimo to można przyjąć, że z przekazem hebrajskich Kronik zwykli odbiorcy mogli zapoznać się w szkołach żydowskich (bet midrasz) lub podczas prywatnego studium Biblii.

W egzegetycznej literaturze żydowskiej wzmianki na temat Księgi Kronik można spotkać także w literaturze midraszyckiej (Midrasz $R a b b a)$, w komentarzach (LevR 1,3; por. RutR 2,1), w której Rab stwierdza: „Księga Kronik została przekazana do wyjaśniania tylko za pomocą midraszu". Poza tym uczeni twierdzą, że mógł istnieć zbiór midraszowych interpretacji opartych na Kronikach, przytaczając na poparcie tej tezy np. fragment b.Pes. 62b: „Od dnia, kiedy Księga Genealogii została ukryta, siła mędrców osłabła, a światło ich oczu przyćmiło się. Mar Zutra powiedział: "Między 'Azel' i 'Azel' [tj. między 1Krn 8,38 i 1Krn 9,34] zostały obarczone czterystoma wielbłądami interpretacji egzegetycznych»"'.15

Wskazówka co do charakteru takiego podejścia znajduje się w b. Meg. 13a, gdzie egzegezę 1Krn 4,18 (imiona różnych postaci oraz znaczenie w nich zawarte łączy z osobą Mojżesza) poprzedza taki komentarz: „Wszystkie twoje słowa stanowią jedność, my zaś wiemy, jak znajdować ich znaczenie wewnętrzne". ${ }^{16} \mathrm{Z}$ tego stwierdzenia wynika, że imiona różnych postaci można uważać za odnoszące się

14 Natomiast z traktatu o szabacie wynika, że odczytywanie obu Ksiąg Kronik mogło być częścią liturgii przynajmniej w jednym ośrodku judaizmu, mianowicie w Nahardei, gdzie czytanie zaczerpnięte z Pism stanowiło pewnego rodzaju haftarę lub minhę w szabat (b. Szab. 116b). Jednak według J. Manna, cały ten fragment w b. Szab. „dotyczy studium w bet hammidrasz, a nie liturgii synagogalnej, jak słusznie zauważa R. Izajasz di Trani”. Takie stanowisko skłania niektórych badaczy do zajęcia stanowiska, że Kroniki mogły być przyjęte do kanonu na jakimś późniejszym etapie. Dyskusję tę przytacza J. S. M c I v o r, The Targum Chronicles. Translated, with Introduction, Apparatus, and Notes, w: K. C a t h c a r t, M. M a h e r, M. M c N a m a r a (red.), The Aramaic Bible: The Targum of Ruth and The Targum Chronicles, t. II, The Liturgical Press, Collegeville (MN )1994, s. 12.

15 Tamże, s. 12; zob. I. K a 1 i m i, The Retelling of Chronicles in Jewish Tradition and Literature, s. 146-148.

16 Tamże, s. 150. 
do jednej i tej samej osoby, jeśli tylko wymagają tego komentarze egzegetyczne.

Fragmenty Kronik są obecne także w homiliach wygłaszanych w synagogach (pesiktas), takich jak Pesikta de Rab Kahana (V w.) oraz Pesikta Rabbati (VI-VII w.). ${ }^{17}$ Choć obie Księgi Kronik nie doczekały się odczytywania w synagodze, to jednak niektóre ich fragmenty przeniknęły w inny sposób.

Brak odczytywania Kronik w liturgicznej tradycji żydowskiej wpłynął także na powstanie i niewielką znajomość Targumu Kronik..$^{18}$ Odniesień do tego targumu brakuje również u średniowiecznych pisarzy. Uczeni wskazują, że Raszi (1045-1105) nie znał żadnego Targumu do Pism, podobnie Dawid Kimchi (1160-1235), który pozostawił po sobie komentarze do wielu ksiąg biblijnych, w tym do Proroków Większych i Mniejszych, a także napisał jako pierwszy komentarz do Kronik nie wspomina ani razu o ich targumie. ${ }^{19}$ Zdaniem Eliasa Lewity (1469-1549) Targum 1-2 Krn nie powstał. ${ }^{20}$ Kalimi zwraca jednak uwagę, że fragmenty Targumu Kronik zostały odnalezione w XIX w. w genizie kairskiej, co może świadczyć, że - w przeciwieństwie do średniowiecznej Europy - był znany w Egipcie. ${ }^{21}$

\section{Targum Kronik - rękopisy i wydania}

Wczesne wydania Biblii rabinicznej nie zawierały Targumu Kronik, brakuje go zarówno w pierwszej edycji Mikraot Gedolot przygotowanej przez Feliksa z Prato, jak i w drugiej edycji Jacoba ben Hayyima, które zostały wydrukowane przez Daniela Bomberga

\footnotetext{
17 J.S. M c I v o r, The Targum Chronicles, s. 13.

18 P. Chu r g i n, The Targum to Hagiographa [hebr.], Horeb, New York 1945,

19 Omawiając fragmenty obu Ksiąg Kronik, które mają paralele obu Księgach Samuela i Królewskich, Kimchi cytuje Tg 1-2 Sm i Tg 1-2 Krl; J.S. M c I v o r, The Targum Chronicles, s. 14.

20 Tamże.

${ }^{21} \mathrm{I} . \mathrm{K}$ a $1 \mathrm{i} \mathrm{m}$ i, The Retelling of Chronicles in Jewish Tradition and Literature,
} s. 236. S. 158 . 
w Biblia Rabbinica w 1517 i 1525 r. ${ }^{22}$ Brak go także obok tekstu hebrajskiego w Biblia sacra polyglotta wydanej w Londynie przez Briana Waltona w latach 1654-1657. ${ }^{23}$ Targum 1-2Krn pojawia się w Hagiographa Chaldaice, wydanym przez Paula de Lagarde w Lipsku w 1873 r., który wykorzystał w nim rękopis erfurcki, posiłkując się rękopisem z Cambridge i jeszcze jednym, bliżej nieokreślonym, kodeksem.

Do naszych czasów zachowały się tylko trzy rękopisy, zawierające tekst Targumu Pierwszej i Drugiej Księgi Kronik:24

1. watykański (V), Cod. Vat. Urb. Ebr. 1, datowany na 1294 r., opublikowany przez R. Le Déauta i J. Roberta, którzy dokonali wiernej transkrypcji rękopisu watykańskiego i wydali go w dwóch tomach z wprowadzeniem, tekstem, przypisami i przekładem na francuski; ${ }^{25}$

2. erfurcki (E), Ms. Or. fol. 1210 i 1211, datowany na 1343 r., jest który przechowywany w Deutsche Staatsbibliothek w Berlinie. Ten obszerny rękopis został opublikowany w dwóch tomach z wprowadzeniem, tekstem, przypisami i przekładem na język łaciński przez M. F. Becka jako Paraphrasis Chaldaica I Libri Chronicorum, Augsburg 1680; także Paraphrasis Chaldaica II Libri Chronicorum, Augsburg 1683;

3. rękopis z Cambridge (C), Ms. Or. Ee. 5,9, datowany na 1347 r., przechowywany na uniwersytecie w Cambridge, został

22 Tamże; też s. 119-120.

23 J. S. M c I v o r, The Targum Chronicles, s. 14.

24 Czwarty rękopis znajdował się w Dreźnie, ale został zniszczony w 1945; zob. P.S. A 1 e x a n d e r, Targum, Targumim, w: D. N. F r e e d m a n (red.), The Anchor Yale Bible Dictionary, t. 6, Doubleday, New York 1992, s. 328; I. K a 1 i m i, The Retelling of Chronicles in Jewish Tradition and Literature, s. 155; J.S. M c I v o r, The Targum Chronicles, s. 14-15.

25 R. L e Dé a u t, J. R o b e r t, Targum des Chroniques (Cod. Vat. urb. Ebr. 1), t. I: Introduction et Traduction, Analecta Biblica 51, Biblical Institute Press, Rome 1971. Tekst hebrajski został udostępniony w elektronicznej wersji: Comprehensive Aramaic Lexicon Project (CAL), Targum Chronicles, Hebrew Union College Jewish Institute of Religion, Cinncinati (OH) 2005. 
opublikowany przez Davida Wilkinsa, który dokończył dzieła rozpoczętego przez Samuela Clericusa pod tytułem Paraphrasis Chaldaica in Librum Priorem et Posteriorem Chronicorum Auctore Rabbi Josepho Rectore Academicae in Syria..., Amsterdam 1715.

W XX w. opracowanie krytyczne wydał także A. Sperber, który opierał się głównie na manuskrypcie erfurckim opublikowanym przez M. F. Becka i wydaniu P. Lagarde. ${ }^{26}$

Zdaniem Le Déaut rękopisy: E, C i V pochodzą ze wspólnego źródła, choć niekoniecznie z tego samego dokumentu. Wykazuje on m.in. zgodność w drobniejszych sprawach, np. pod względem specyficznych konstrukcji słownych, jednak w innych miejscach są obecne odmienne formy tych samych słów. Po przeprowadzeniu dokładniejszych badań Le Déaut doszedł do wniosku, że między tymi manuskryptami zachodzą bardziej złożone relacje. Stwierdził bowiem, że C i V mają ze sobą więcej cech wspólnych niż z E. ${ }^{27}$

\section{Autor, datacja i pochodzenie}

Tradycyjnie autorstwo Targumu do Pism, w tym Targumu Kronik, jest przypisywane amoraicie z trzeciego pokolenia uczonych

26 A. S p e r b e r, The Bible in Aramaic, IVA, Leiden 1968, s. 3-119. Wydania Lagarde'a i Sperbera są niemal identyczne. Oprócz tekstu Sperber dodaje w swej publikacji uwagi na temat wieku i miejsca pochodzenia tego dokumentu, a obok tekstu Tg 1-2Krn w sąsiednich kolumnach umieszcza teksty paralelne z Tg 1-2Sm i $\mathrm{Tg} 1-2 \mathrm{Krl}$.

$27 \mathrm{Na}$ potwierdzenie tego przytacza następujące przykłady: czasownik ,wysyłać" w C i V zapisywany jest $\breve{s}-d-r$, E natomiast podaje $̌$ s̆lh. C i V wstawiają do tekstu warianty alternatywne (zresztą bardzo podobne, np. Tg 1Krn 11,16; 18,13; 21,27), natomiast w E nie ma to miejsca. C i V stosują takie same specyficzne konstrukcje słowne (np. Tg 1Krn 10,7; 28,9.12; 2Krn 2,11), posługują się taką samą terminologią (Tg 2Krn 4,16; 14,5), występuje w nich taka sama dittografia ( $\operatorname{Tg} 2 \mathrm{Krn}$ 18,33), podobnie takie same warianty $(\operatorname{Tg} 2 \mathrm{Krn} 33,8 ; 36,10)$. Jednocześnie Le Déaut zwraca uwagę na różnice, które występują w C i V (Tg 1Krn 3,12; 9,40; 2Krn 7,6; 10,7), a niektóre parafrazy w obu rękopisach zbudowane są inaczej (Tg 1Krn 2,17-18; 4,24). 
babilońskich Rab Josefowi Ślepcowi z Pumbedity (290-320). ${ }^{28} \mathrm{Hi}-$ potezę, że autorem Targumu do Pism był Rab Josef, podważano już w średniowieczu, odrzucał ją też Elias Levita.

Współcześnie badacze, tacy jak R. Le Déaut i J. Robert ${ }^{29}$ oraz J. S. McIvor, ${ }^{30}$ uważają, że Targum Kronik mógł mieć początek w późnej erze talmudycznej, jednak ostateczną formę przybrał nie wcześniej niż w VIII w. Dzieło to rozwijało się stopniowo i było efektem działalności kilku pokoleń targumistów. Możliwe jest również, że autor Targumu Kronik korzystał z różnych starożytnych źródeł, które stopniowo rozwijał, natomiast sama redakcja nie została poddana takiemu rozwojowi. ${ }^{31}$

Uczeni $^{32}$ zwracają również uwagę na fakt, że Targum Kronik został napisany w palestyńskim dialekcie aramejskim, podobnie jak targumy jerozolimskie (zwane także palestyńskimi), ${ }^{33}$ a co za tym idzie pochodzi z Palestyny. ${ }^{34} \mathrm{Z}$ tego powodu targum ten mógł

28 Wilkins przypisuje go do akademii w Syrii, natomiast Rosenberg i Kohler uważają to za błąd i opowiada się za akademią w Surze. Rab Josefowi Ślepcowi (zm. 320 r.), traktat Bawa Kamma przypisuje tytuł „komentatora”, ale wydaje się nieprawdopodobne, żeby jakiś amoraita z Babilonii był autorem targumu, który tak mocno akcentuje sprawy palestyńskie; J.S. M c I v o r, The Targum Chronicles, s. 14.

29 Zob. R. L e Dé a u t, J. R o be r t, Targum des Chroniques, s. 24-28.

30 J.S. M c Iv o r, The Targum Chronicles, s. 15.

${ }_{31}$ I. K a $1 \mathrm{i} \mathrm{m} \mathrm{i,} \mathrm{The} \mathrm{Retelling} \mathrm{of} \mathrm{Chronicles} \mathrm{in} \mathrm{Jewish} \mathrm{Tradition} \mathrm{and} \mathrm{Literature,}$ s. 159.

32 Zob. P. C hu rg i n, The Targum in the Hagiographa, s. 263-266.

33 Także Rosenberg i Kohler uważają, że w Tg 1-2Krn jest zapisany palestyńskim dialektem aramejskim.

34 Wg Le Déauta i Churgina autor Tg 1-2 Krn znał ten targum, bo przemawia za tym wiele zgodności między obydwoma dokumentami, np. 1Krn 10,3.8 i 1Sm 31,3.8 (co do pełniejszej listy zob. Le Déaut). Z drugiej strony w Tg 1-2Krn istnieją parafrazy, których brak w TgJ, czasem też zachodzą rozbieżności w tłumaczeniach obu dokumentów. Zdaniem Churgina swego czasu istniał targum do Proroków recenzji palestyńskiej, który redaktor Tg 1-2Krn miał przed oczami. Obecnie dokument ten się nie zachował, przetrwały jedynie jego fragmenty, o czym mogłyby świadczyć niektóre uzupełnienia w Codex Reuchlinianus, często wprowadzane słowami: ,Tg Jerozolimski”. 
być prawie zupełnie nieznany średniowiecznym uczonym. Zdaniem Sperbera, ci, którzy stworzyli Tg 1-2Krn, posługiwali się językiem aramejskim w mowie potocznej, dlatego potrzebowali tłumaczenia, aby zrozumieć Biblię. Jednocześnie pozostawali pod wpływem grecko-rzymskiej cywilizacji, która ich otaczała i której wpływom ulegali. Potwierdzają to, m.in., występujące w targumie zapożyczenia greckich i łacińskich słów, ${ }^{35}$ których musieli używać, a które stopniowo weszły do mowy potocznej. Takie zapożyczenia nie występują w literaturze żydowskiej spoza Palestyny. Ponadto targum ten przejawia zainteresowanie toponimią Palestyny, instytucjami związanymi ze studium Tory oraz hagadą, obecną w tzw. Targumie Jerozolimskim Pięcioksięgu (Targumie Fragmentarycznym, ale przede wszystkim w Targumie Pseudo-Jonatana, który wcześniej był zaliczany do Targumów Jerozolimskich). ${ }^{36}$

Jeśli chodzi o środowisko, w którym mógł powstać Targum Kronik, to z braku obecności Pierwszej i Drugiej Księgi Kronik w liturgii żydowskiej należy go szukać w szkołach ${ }^{37}$ lub też w prywatnym studium, ${ }^{38}$ które jednak jest trudne do udokumentowania. W tym przypadku pewną wskazówką mógłby być duży nacisk na studiowanie Tory oraz pochwały pod adresem tych, którzy zostali uczniami Prawa, obecne w Tg 1-2Krn. ${ }^{39}$

35 Listę 57 takich słów, które są użyte w Tg 1-2Krn przedstawia J.S. M c I v o r, The Targum Chronicles, s. 31-33.

36 J.S. McIvor wskazuje na obecność w tle TgPsJ zwłaszcza w tych fragmentach Ksiąg Kronik, które mają paralele w Pięcioksięgu, szczególnie w 1Krn 1-2 (np. TgPsJ Wj 35,26 z Tg 1 Krn 2,18).

37 Zdaniem Rosenberga i Kohlera chodzi o jakąś kompleksową działalność nauczycielską (umfassenden Lehrthätigkeit), obejmującą objaśnianie całej Biblii, której centrum znajdowało się w bet hammidrasz; zob. M. R o s e n b e r g, K. K o h 1 e r, Das Targum zur Chronik, Jüdische Zeitschrift für Wissenschaft und Leben 8/1870, s. 274-276.

38 R. K a s he r, The Aramaic Targumim and Their Sitz im Leben, WCJS 9, Panel Sessions: Bible Studies and Ancient Near East, Jerusalem 1988, s. 75-85.

39 I. K a $1 \mathrm{i} \mathrm{m}$ i, The Retelling of Chronicles in Jewish Tradition and Literature, s. 159 . 


\section{Strategie i techniki translatorskie oraz elementy egzegezy w przekładzie aramejskim}

Największym wyzwaniem dla tłumacza był przede wszystkim przekład hebrajskiego tekstu Księgi Kronik na język aramejski, gdyż miało to być tłumaczenie jasne, jednoznaczne i zrozumiałe dla odbiorców. Z tego względu dokonywał on pewnych modyfikacji, tak by targum służył nie tylko zbudowaniu adresatów, ale także przekazywał elementy tradycji, która ewoluowała.

Prezentowana przez Kronikarza w tekście biblijnym przeszłość wymagała odpowiedzi w teraźniejszości. Przez wybór i ukazywanie tradycji Izraela, stereotypowe przedstawianie postaci, np. prezentację Dawida i Salomona jako idealnych królów, a więc postaci wzorcowych, dała możliwość oceny dawnych pokoleń, aby odbiorcy Kronik mogli zrozumieć sytuację im współczesną, wskazując, że ich tożsamość jest związana z wszystkimi minionymi pokoleniami Izraela. Ocena ich obecnej sytuacji miała wywołać odpowiednią reakcję. Kronikarz wskazywał, że opieka JHWH, która trwała przez pokolenia, zależy od postępowania narodu. Zarówno w przeszłości, jak i w sytuacji przedstawianej w Kronikach, Izrael nadal był zobowiązany do praktykowania prawdziwego kultu JHWH. Odbiorcy Kronikarza, dzięki jego dziełu, mogli poznać, co przynosi błogosławieństwo, a co sprowadza katastrofy. Wiedzieli, że każda sytuacja mogła ulec zmianie, w zależności od tego, czy ktoś szukał, czy też odwracał się od JHWH. Kronikarz, przez ponowne przedstawienie przeszłości, wzywa naród do właściwych relacji z JHWH i daje mu nadzieję na błogosławieństwo.

Przekaz Kronikarza zostaje podjęty przez targumistę w nowej sytuacji. Podobnie jak w przypadku innych aramejskich przekładów biblijnych, również w Targumie Kronik targumista stosuje określone techniki translatorsko-egzegetyczne, które wynikają z różnego rodzaju trudności związanych z tekstem hebrajskim a także rozszerzenia i uzupełnienia, wynikające z rozwoju koncepcji teologicznych 
w kontekście przeszłości Izraela i teraźniejszości współczesnego mu pokolenia. ${ }^{40}$

Zastosowana przez targumistę strategia adaptacji, to jest przekształcenia informacji zawartej w tekście biblijnym w celu dostosowania go do wiedzy czytelnika, mogła wynikać z próby harmonizacji z innymi tekstami biblijnymi. Zachodzi tu również proces targumizacji przez włączenie tradycji hagadycznych i midraszyckich. Podobnie jak w przypadku paraleli biblijnych obu Ksiąg Samuela i Królewskich z Księgami Kronik, występuje tu także wiele paraleli do innych targumów, które znał tłumacz Tg 1-2Krn. Korzystał on z Tg 1-2Sm i Tg 1-2Krl, ale także z Targumów Pięcioksięgu, szczególnie w początkowych partiach narracyjnych. Targum Kronik często podaje interpretacje, które znajdują się w Targumach Pięcioksięgu, zwłaszcza w Targumie Pseudo-Jonatana, szczególnie w kontekście kultu sprawowanego w świątyni. ${ }^{41}$ Jednak niektóre argumenty przemawiają też za tym, że czerpie z Targumu Onkelosa. ${ }^{42}$ Pewne paralele z Tg 1-2Krn występuje w odniesieniu do Targumów Pism, np. w Tg Rt i Tg Pnp. ${ }^{43}$

Podstawowe techniki translatorskie w Targumie Kronik

Należy podkreślić, że generalnie tłumacz wiernie trzyma się oryginału hebrajskiego, ${ }^{44}$ nie licząc miejsc, w których stosuje określone

40 P.V.M. F le s h e r, B. C h il t o n, Targums: A Critical Introduction, Baylor University Press, Waco (TX) 2011, s. 257.

${ }^{41}$ Tamże. Na ten temat zob. A. K u ś m i r e k, Świątynia jerozolimska $w$ targumach, Collectanea Theologica 2/2009, s. 65-76.

42 J.S. M c I v o r, The Targum Chronicles, s. 18-21.

43 P.V.M. F 1 e s h e r, B. C h i 1 t o n, Targums, s. 257; zob. też. M. B a r a n i a k, Zjawisko targumizacji na podstawie Targumu do Pieśni nad Pieśniami. Krytyczna edycja tekstu z manuskryptu M 1106 z analiza egzegetyczno-hermeneutyczna $i$ thumaczeniem, Dom Wydawniczy ELIPSA, Warszawa 2013.

44 Np. nazwy własne targumista oddaje za pomocą odpowiadającego im terminu aramejskiego, który pokrywa się znaczeniowo z terminem hebrajskim, np. w $2 \mathrm{Krn}$ 16,6 nazwa miejsca $m s ̣ p h$ - „strażnica”, ,wieża obserwacyjna” to w Tg skwt' „strażnica”, „wieża obserwacyjna”. W 1Krn 1,30 pięciu synów Izmaela otrzymuje 
zmiany, czy też dodaje coś od siebie. ${ }^{45}$ Zmiany wprowadzone przez tłumacza mogły wynikać z trudności tekstualnych, ${ }^{46}$ dotyczą głównie słów lub wyrażeń niejasnych, nieznanych, ${ }^{47}$ abstrakcyjnych lub dwuznacznych, ${ }^{48}$ które targumista zmienia na zrozumiałe, aktualne, konkretne i szczegółowe. ${ }^{49}$ Aktualizacja różnych informacji dotyczy bardzo często nazw własnych, szczególnie zaś określeń geograficznych i etnicznych, ${ }^{50}$ a także nazw monet. ${ }^{51}$

Uzupełnienia, rozszerzenia, a nawet komentarze do tekstu hebrajskiego miały różne źródła. ${ }^{52}$ Mogły one wynikać ze znaczenia słowa pokrewnego ${ }^{53}$ albo też opierać się na faktycznym lub domniemanym

pokrewne hebrajskim imiona aramejskie, np. $d w m h$ - „cisza”, „milczenie” to aram. štwq' - „cisza”, „milczenie”, a w 1Krn 4,28 „Hazarshual” (TM) staje się „Hazartala” (Tg), przy czym część słowa zapisana kursywą to odpowiednio po hebr. i aram. „lis”. W niektórych miejscach jeden termin aramejski zastępuje dwa lub więcej słów hebrajskich. W 2Krn 20,18 dwa hebr. czasowniki: qdd - „kłaniać się” i $n p l-$ „upadać” oddane zostają za pomocą jednego kr' - „kłaniać się”. W 2Krn 20,21 trzy hebr. czasowniki: šyr - „śpiewać” i hll - „wychwalać” oraz ydh - „wyznawać”, „uznawać” zastąpione zostają jednym $s b h$ - „wychwalać”. Takie podejście widać najlepiej w stosowaniu aram. czasownika qtl - „zabić”, który często odpowiada hebr. hrg - „zabić” (1Krn 7,21), Hiphil mwt - ,skazać na śmierć” (2Krn 25,4), Hiphil $n k h$ - ,porazić” (1Krn 18,5), dqr-,przebić”, ,zadźgać” (1Krn 10,4), hll-, ,przebić”, „zgładzić” (1Krn 10,1), šht - „zniszczyć” (2Krn 24,23).

45 J.S. M c I v o r, The Targum Chronicles, s. 18-21.

46 Np. TM 2Krn 35,21: „Nie przeciwko tobie, ty dzisiaj”, Tg: „To nie jest przeciwko tobie, że wyruszam do walki, bo ty dzisiaj mnie atakujesz".

47 Np. TM 1Krn 18,17: „Keratyci i Pelyzyci”, Tg: „łucznicy i procarze”; TM 2Krn 9,16: „dom [z] lasu Libanu”; Tg: „dom ochłody królów”, czyli „królewski letni pałac”.

48 Np. TM 1Krn 17,1: „Ja mieszkam w domu cedrów”, Tg: „Ja mieszkam w domu, który wyłożony jest belkami cedrowymi”; TM 2Krn 12,12: „Lecz w Judzie były również dobre rzeczy”, Tg: „Na tych z domu Judy postanowił sprowadzić pomyślność”.

49 Np. TM 1Krn 5,22: „,do wygnania”, Tg: „do wygnania Sennacheryba”; TM 2Krn 32,21: ,anioł”, Tg: ,,anioł Gabriel”.

50 Np. TM 1Krn 18,9 „Chamat”, Tg: „Antiochia”, czasem zostaje „Chamat”: np. Tg 1Krn 18,3; TM 1Krn 1,29 „Kedar”, Tg: „Arabia”.

${ }^{51}$ Np. TM 1Krn 29,7 „talent”, Tg: ,centenarium”.

52 J.S. M c I v o r, The Targum Chronicles, s. 22-24.

53 Np. w Tg 1Krn 4,15 wypowiedź Kaleba nawiązuje do imienia jego ojca (Jefunnego); w Tg $1 \mathrm{Krn}$ 1,19 wypowiedź na temat Joktana (yqtn) opiera się na słowie 
znaczeniu słowa hebrajskiego. ${ }^{54}$ Czasami targumista stosował charakterystyczną technikę, która polegała na dzieleniu danego słowa na sylaby i podawaniu ich interpretacji. ${ }^{55}$ Wykorzystywał wyrażenia synonimiczne, którym nadawał odrębne objaśnienia. ${ }^{56}$ Wprowadzone rozszerzenia mogły również opierać się na innym wariancie tekstu. ${ }^{57}$

\section{Zmiany wynikające z rozwoju koncepcji teologicznych}

Podobnie jak w innych targumach, zmiany doktrynalne dotyczą przede wszystkim koncepcji Boga, relacji między Bogiem a człowiekiem, pośredniczącej roli aniołów, fundamentalnego znaczenia Tory, ale także zjawiska proroctwa oraz szacunku dla przodków i ich zasług (zěk ût 'ābôt)), który prowadzi do gloryfikacji ważnych bohaterów biblijnych. ${ }^{58}$

Targum Kronik wyraźnie akcentuje transcendencję i wyłączność egzystencji jedynego Boga. ${ }^{59} \mathrm{~W}$ tym celu targumista dodaje teksty,

wyglądającym podobnie (qt’ - „odcinać”). W Tg 2Krn 13,5 wzmianka o ,przymierzu soli" prowadzi do uzupełnienia, które mówi o uczynieniu słodkimi wód morskich.

54 Np. 1Krn 1,10: Nemrod od mrd - „,buntować się”; 1,20: Hazar Mawet - „dziedziniec śmierci”.

55 Np. w 1Krn 16,3 każdy człowiek dostaje po bochenku chleba i špr. Targumista skupia się na jego pierwszej sylabie “š i kojarzy ją ze słowem oznaczającym ,sześć”, (które wygląda dość podobnie), a po połączeniu z drugą sylabą ( $p r)$, która sama w sobie oznacza „wół”, otrzymuje w rezultacie, że każdy dostał po jednej szóstej wołu!

56 Np. 1Krn 28,2 TM: „mój bliźni” i „mój naród” - Tg: „mój bliźni, dom Izraela, i mój naród, prozelici, którzy w swych miastach".

57 Np. 1Krn 13,9 jest „,klepisko Kidon”, a paralelny tekst 2Sm 6,6 mówi o „,klepisku Nakon”, które w Tg Sm staje się „miejscem przygotowanym” na podstawie rdzenia $k w n$ (Nakon) - Tg 1Krn 13,9.

58 J.S. M c I v o r, The Targum Chronicles, s. 24-31. J. R i b e r a - F 1 o r i t, Doctrinal Peculiarities of TgChr, w: J. N e u s n e r, A. J. Ave r y- P e c k (red.), Encyclopedia of Midrash, Brill, Leiden 2005, s. 170-173; por. L. S m o l a r, M. A b e r b a c h, Studies in Targum Jonathan to the Prophets, Ktav Pub \& Distributors, New York 1983, s. 129-227.

59 E. L e v i n e, The Aramaic Version of the Bible. Contents and Context, Walter de Gruyter, Berlin 1988. 
w których wychwala Bożą chwałę i majestat, Jego moc w dziele stworzenia, wyzwolenie Jego ludu i Jego suwerenne panowanie nad wszystkim, np. „Twoje, o PANIE, jest panowanie n a n i e b o s kło n i e i wywyższony jesteś ponad wszystkich a n i o ł ó w, k tó r z y są w niebie, i ponad tych wszystkich, którzy ustanowieni są przywódcami na ziemi" $(\operatorname{Tg} 1 \mathrm{Krn} 29,11) .{ }^{60}$

Tłumacz Kronik, w charakterystyczny dla targumizmu sposób, stara się ukazać relację Boga z człowiekiem, stosując techniki, które wykluczają ten bezpośredni kontakt. W tym celu najczęściej używa terminu memra, którego podstawowe znaczenie to „słowo” (od rdzenia 'mr - „mówić”). Obecność w tekście tego terminu akcentuje najczęściej na Boże działanie. Jednym z najbardziej powszechnych zastosowań tego słowa jest przekład sformułowania „Bóg mu pomógł” lub „Bóg był z nim” w sensie pomocnej lub wspierającej obecności, które w targumie jest tłumaczone następująco: „Memra PANA było mu z pomocą" (np. Tg 1Krn 17,2.8). ${ }^{61} \mathrm{~W}$ wersji aramejskiej, mimo zasady dotyczącej mówienia z dystansem o relacjach Boga z człowiekiem, targumista akcentuje działanie Boga lub Jego memra dla dobra Jego ludu, by go wyzwolić, okazać mu pomoc czy podnieść na duchu (Tg 1Krn 17,21; 29,11; Tg 2Krn 28,3).

Aramejski tłumacz nie dopuszcza do sytuacji, w której słowo „Bóg” byłoby używane w odniesieniu do kogokolwiek lub czegokolwiek innego poza Stworzycielem nieba i ziemi, JHWH, Bogiem

60 Spacja użyta w cytacie odpowiada dodatkom do tekstu hebrajskiego wprowadzonym przez aramejskiego tłumacza.

${ }^{61}$ W innych miejscach Memra wydaje się pełnić rolę zaimka osobowego, np.: „I żałował w swoim Memra” (Tg 1Krn 21,15). Mimo że zdarzają się tė̇ miejsca, w których Memra używane jest w odniesieniu do ludzi, przy czym za każdym razem jako zaimek osobowy. W Tg 2Krn 16,3 Asa mówi do Ben-Hadada: „Jest przymierze między moim memra i twoim memra” (TM: „między mną i tobą”). Tg 2Krn 32,1: „PAN postanowit w swym Memra”, w tym samym wierszu: „Sennacheryb powiedział w swym memra" (por. Tg 2Krn 23,16; 25,19). Są też przykłady, kiedy JHWH działa bez pośrednictwa Memra, np. Tg 1Krn 28,4-5: „PAN wybrał”, „PAN dał”. Szerzej na temat Memra zob. m.in. A. C h e s t e r, Divine Revelation and Divine Titles in the Pentateuchal Targumim, TSAJ 144, J.C.B. Mohr, Tübingen 1986, s. 293-312. 
Izraela, PANEM wszechświata. W tym celu wyklucza dwuznaczność lub nieprecyzyjny język, tłumacząc słowo „Bóg”, gdy występuje w status absolutus, ${ }^{62}$ jako imię własne hebr. JHWH. ${ }^{63}$ Tam, gdzie Tekst Masorecki mógłby sugerować istnienie jakichś innych bóstw, meturgeman używa zazwyczaj terminu $t^{\star} w w t^{6}$ (od rdzenia $t^{6} w w t^{6}-$ „sprowadzać na manowce”), który należy przetłumaczyć jako „idol”,

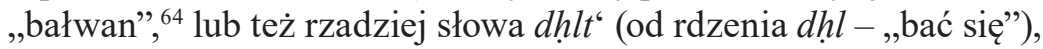
o znaczeniu „obiekt strachu” lub ,przedmiot czci”. ${ }^{65}$ Podobnie targumista tłumacz te miejsca, gdzie jest mowa o ludziach lub przedmiotach związanych z tymi ,,idolami/bałwanami”. ${ }^{66}$

Wzorem wszystkich innych targumów również Tg 1-2Krn konsekwentnie podkreśla bezcielesność Boga i stara się przekształcić antropomorfizmy i antropopatyzmy, ponieważ Bogu nie można przypisywać ani części ciała, ani ludzkich uczuć i emocji, ani też jakichkolwiek ludzkich czynności. Dotyczy to przede wszystkim

62 Zapis skrótem w postaci spółgłoski: „he” lub JJJ - JHWH.

63 Zob. np. Tg 1 Krn 5,20; 1 Krn 6,34. Podobnie czyni w przypadku takich zestawień jak: TM: „dom Boży” - Tg: „,sanktuarium domu JJJ” (np. Tg 1Krn 9,11.13.26.27; Tg 2Krn 3,3; 4,11.19; 5,1.14; 7,5); TM: ,arka Boga” - Tg: ,arka JJJ” (np. Tg 1Krn 13,6.7.14; 15,2; 16,1; Tg 2Krn 1,4); TM: „mąż Boży” - Tg: ,prorok PAŃSKI”; Np. Tg 1Krn 23,14; Tg 2Krn 11,2. Tam, gdzie występuje zwrot „szukać PANA” targumista wprowadza rozbudowaną formę ,szukać pouczenia sprzed PANA” (np. Tg 2Krn 11,6) lub „szukać bojaźni PAŃSKIEJ” (Tg 1Krn 28,9 por. Tg 2Krn 15,2.15). Niektóre z określeń zostają zastąpione w języku aramejskim bardziej właściwymi według targumisty, np. „ofiary wspólnotowe” (šlmym - „zapokojne”) stają się „ofiarami [z] rzeczy świętych” (zob. Tg 2Krn 30,22; 33,16), a czasownik ,słuchać” i ,słyszeć” zastąpiony często czasownikiem ,otrzymać od” (np. Tg 1Krn 10,10; Tg 2Krn 10,15.16; $13,4)$.

${ }^{64}$ M.in. 2Krn 7,19.22; 28,25; 34,25.

65 Zob. 1Krn 16,26 TM: „gdyż wszyscy bogowie narodów to rzeczy bezwartościowe” - Tg: „gdyż wszystkie bałwany narodów to przedmioty czci, które do niczego się nie nadaja".

${ }^{66}$ W TM ,ołtarz” (JHWH lub pogański) to po hebr. mzbh, w targumie termin ten używany jest tylko w odniesieniu do ołtarzy JHWH, ołtarze pogańskie zaś są określane za pomocą terminu ' $g w r$ ' - „stos kamieni”, podobnie w przypadku pojęcia hebr. khn - „kapłan”, w targumie odnosi się tylko do kapłana JHWH, natomiast na określenie kapłana pogańskiego jest stosowany termin kwmr'. 
części ciała ludzkiego, które Tekst Masorecki przypisuje Bogu (ręce, ${ }^{67}$ nogi, ${ }^{68}$ usta $^{69}{ }^{6}$ oczy,${ }^{70}$ uszy $\left.^{71}\right)$, względnie czynności, które organy te wykonują (dotykanie, chodzenie, widzenie, słuchanie itd.). ${ }^{72}$ Mimo że meturgeman stosuje ten zabieg bardzo często, to zdarza się, że nie jest w tym do końca konsekwentny. ${ }^{73}$

Ponadto do wyrażenia czynności wykonywanych przez różne części ciała targumista często stosuje stronę bierną. ${ }^{74} \mathrm{~W}$ tym kontekście warto przytoczyć specyficzną dla targumów formułę z użyciem czasownika „objawiać” w stronie biernej - ,zostało objawione": 75 „Memra PANA z o s tało objaw i o n e" (Tg 2 Krn 7,12), ${ }^{76}$ stosowane jako odpowiednik także dla innych hebrajskich czasowników, np. „a kiedy zostało objawione przed PANEM”

${ }^{67}$ Np. 2Krn 6,4 TM: „który ręką wypełnił” - Tg: „który dobra wola wypełnił”. 2Krn 6,15 TM: „wypowiedziałeś swymi ustami i wypełniłeś to swą ręką” - Tg: „postanowileś przez swoje memra i przez swa wole (to) spowodowates”.

${ }^{68}$ 1Krn 28,2 TM: ,podnóżek stóp naszego Boga” - Tg: „podnóżek tronu chwaty Pana".

${ }^{69}$ 2Krn 36,12 TM: „prorok, który przemawiał z ust PANA” - Tg: „prorok, który prorokowat mu z ust Memra PANA".

${ }^{70} \mathrm{~Np}$. w odniesieniu do króla: 2Krn 14,1 TM: „czynił to co złe w oczach PANA” - Tg: „,zynił to co złe przed PANEM”; ale także do ludu, np. 1Krn 13,4 TM: „było to słuszne w oczach całego ludu” - Tg: „,było to słuszne przed całym ludem” (por.: Tg 2Krn 30,4); zob. też: 2Krn 6,20 TM: „żeby Twe oczy mogły być otwarte na ten dom" - Tg dosł.: ,żeby moglo być przed Toba upodobaniem, byś chronit ten dom" (por. 6,40; 7,15). Natomiast w 2Krn 16,9 sformułowanie z TM: „oczy PANA spoglądają na całą ziemię" pozostają także w Tg.

${ }_{71} 1$ Krn 28,8 TM: „w uszach naszego Boga” () - Tg: „przed Memra PANA”. Natomiast w 2 Krn 6,40; 7,15 słowo „uszy” pozostaje w Tg.

72 J.S. M c I vo r, The Targum Chronicles, s. 26-27.

${ }^{73}$ Np. w 1Krn 28,19 TM: „To wszystko na piśmie z ręki Pana”, które w targumie nie ulega zmianie. A niekiedy dodaje nawet w 2Krn 25,8 TM: „bo moc jest z Bogiem” - Tg: ,bo moc jest $w$ ręce PANA”.

${ }_{74}$ Np. 2Krn 34,27 TM: „usłyszałem” (TM) - Tg: ,zostało ustyszane przede Mna”, choć następnie jest zachowana też fraza: „PAN rzekł”. Czasownik ,słyszeć” targumista bardzo często zastępuje zwrotem „przyjąc od" (m.in. 2Krn 6,23.25.27.30.33).

${ }^{75} \mathrm{Na}$ temat znaczenia i użycia strony biernej w targumach rdzenia $g l$ '; zob. A. Ch e s t e r, Divine Revelation and Divine Titles, s. 8-263.

${ }^{76}$ 2Krn 7,12: „PAN ukazał się”. 
(Tg $2 \mathrm{Krn} 12,7) .{ }^{77}$ Jeszcze innym sposobem ukazania dystansu między Bogiem a człowiekiem jest tłumaczenie przyimka „do” lub „dla” z tekstu hebrajskiego za pomocą $q d m$ - ,przed” w odniesieniu do Boga, np.: „ofiarować chwałę przed PANEM i i mieniu P A N A" (Tg 2Krn 5,13). ${ }^{78}$

Ponieważ targumista zdaje sobie sprawę, że Bóg jest zbyt wielki i potężny, by można było Go zmieścić w kategoriach ziemskich (Tg 2Krn 2,5), czy też bezpośrednio o Nim mówić i używa zamiennego sformułowania, kiedy jest mowa o obecności JHWH: „Szechinah PANA obrała sobie za siedzibę dom s a n k t u a ri u m" (Tg 2Krn 7,10). Do kwestii obecności Szechinah w świątyni i w Jerozolimie Tg 1-2Krn wraca wielokrotnie. Kilkakrotnie podejmuje też temat obrzędów sprawowanych w świątyni, jej personelu i sprzętów świątynnych. Wprowadza między innymi nazwę na określenie ofiar, składanych w świątyni, nazywając je „ofiarami (z) rzeczy świętych", które były rozdzielone między ludzi w liczbie ,jednej szóstej wołu i jednej szóstej hinu wina" (Tg 1Krn 16,3). Wymienia personel odpowiedzialny za poszczególne miejsca w świątyni (Tg 1Krn 26). Opisuje elementy wyposażenia świątyni, np. „ba se n, który w ykonał Besaleel (...) do uświęcenia a rcyka płana" (Tg 2Krn 4,6).

W kontekście rozwoju koncepcji teologicznych należy zwrócić uwagę, że poza rozbudowaną angelologią, Tg 1-2Krn niemal zupełnie pomija tematy eschatologiczne i mesjanistyczne. Na temat Mesjasza jest tylko jedna enigmatyczna wzmianka w Tg 1Krn 3,24: „A synami Eljoenaja [byli]: Hodawjahu, Eljaszib i Pelaja, Akub, Jochanan, Delaja i Anani - on [jest] Królem Mesjaszem, który będzie objawiony we wszystkich siedmiu".

77 Krn 12,7: ,a kiedy PAN zobaczył”.

78 2Krn 5,13: „,chwalić PANA”. Zob. też 2Krn 32,23-24; 1 Krn 21,8.14; 23,31. 
Jeśli chodzi o angelologię, ${ }^{79}$ to w Tg 1 i 2 Krn jest mowa o ,aniołach p o słany ch przez PANA"80 (np. Tg 1Krn 21,18.30), którzy działają w Jego imieniu i zgodnie z Jego wolą, pozostając pod Jego kontrolą. Targumista wprowadza aniołów w miejsce „niebios” z 1Krn 16,31 TM (,,a n i ołowi e na w y sokości”) a w kilku przypadkach termin ten pojawia się w zastępstwie samego Boga (m.in. Tg 1Krn 17,21). Grupy aniołów odpowiadają zastępom niebieskim (np. Tg 1Krn 12,23: „niczym obóz aniołów PAŃSKICH”). ${ }^{81}$ Aniołowie są też obecni na Synaju przy przekazywaniu Prawa (Tg 1Krn 29,11). $\mathrm{Z}$ imienia zostają wymienieni aniołowie Gabriel i Michał, którzy zostali zesłani, aby zniszczyć Asyryjczyków (Tg 2Krn 32,21 por. Dn 8,$16 ; 12,1)$.

Zgodnie z prezentowaną przez Tg 1-2Krn koncepcją Boga „wywyższonego” wiąże się możliwość „poznania” Go, które polega na oddaniu się studium Prawa i jego zachowywaniu. Targumista przykłada w swoim tłumaczeniu wielką wagę, aby przedstawić odbiorcom tak sprawy, by wszystko było zgodne z Prawem, według tradycji żydowskiej, zawartej w stwierdzeniu: ,jak nakazał Mojżesz”.

Istotne znaczenie ma tu postawa postaci biblijnych, które stają się wzorami dla odbiorców współczesnych targumistom, są to przede wszystkim: Mojżesz i Dawid. Tam, gdzie pojawiają się wzmianki na ich temat, do tekstu oryginału wprowadzane są rozszerzenia. Często wskazują one na gorliwość tych postaci w poznawaniu i przestrzeganiu Prawa. Ich sławę i znaczenie podkreślają dołączone hymny pochwalne. Opisy te odzwierciedlają rozwiniętą doktrynę o wyjednywaniu zasług przez ludzi pobożnych, która odgrywa istotną rolę w targumach, podobnie jak w literaturze talmudycznej i homiletycznej:

79 Na temat aniołów w targumach do Pięcioksięgu zob. M.S. W r ó b e 1, Wprowadzenie do Biblii Aramejskiej, Wydawnictwo Gaudium, Lublin 2017, s. 250-256.

80 Targumista określa ich słowem hebr. i aram. $m l$ ' $k$, z jednym wyjątkiem $\operatorname{Tg} 1 \mathrm{Krn} 16,31$ - gdzie jest zapożyczony termin 'ngly.

${ }^{81}$ 1Krn 12,23 TM: „niczym armia Boga”; 1Krn 14,15 TM: „odgłos maszerujących po wierzchołkach drzew balsamowych”- Tg: „odgłos aniołów, którzy przybywaja ci z pomoca". 
zasługa jednego człowieka (hebr. zĕkût) przynosi korzyść drugiemu człowiekowi lub całej wspólnocie. ${ }^{82}$

Wśród głównych bohaterów, którzy pozwalają łączyć targumiście ukazaną w tekście biblijnym przeszłość z teraźniejszością, aby Izrael nadal był błogosławiony przez Boga, należy wymienić Izaaka, Mojżesza i Dawida.

Według targumów to właśnie zasługa związana z ofiarowaniem Izaaka (TgPsJ Rdz 22,14) najpierw powstrzymała Boży gniew na Izraela (Tg 1Krn 21,15), potem stała się teologicznym fundamentem wybudowania świątyni przez Salomona (Tg 1Krn 3,1). ${ }^{83}$

Zalety i osiągnięcia Mojżesza w spektakularny sposób opisuje Tg 1Krn 4,18: „Jego żona, Judejka, w y c how ała Mojże s z a po tym,jak wyciągnęła go z wody. Nazwała go: Jered, bo sprowadził mannę dla Izraela; dowódca Gedora, bo odbudował Izraela z ruin; Cheber, bo zjednoczył Izraela z ich Ojcem, który jest w niebie; dowódca Soko, bo dom Izraela okrył swymi zasługami; Jekutiel, bo za jego dni Izrael 40 lat czeka 1 na pustyni na Boga, który jest w niebie; dowódca Zanoacha, ponieważ przez wzgląd na niego Bóg przebaczył Izraelowi jego grzechy. Te imiona $\mathrm{nadała} \mathrm{mu} \mathrm{Bitia,} \mathrm{córka} \mathrm{faraona,} \mathrm{[pod} \mathrm{wpływem]} \mathrm{ducha}$ proroctwa. Została prozelitką i poślubił ją Mered,który był Kalebem, ponieważ sprzeciwił się radzie szpiegów".

Tekst Masorecki 1Krn 4,18 przekazuje jedynie tyle: „Żona jego Judejka, urodziła Jereda, ojca Gedora, Chebera, ojca Soko, i Jekutiela, ojca Zanoacha. To są synowie Bitji, córki faraona, którą pojął [za żonę] Mered".

82 J. N e u s n e r, Zekhut, w: J. N e u s e n r, A.J. Ave r y - P e c k, W. S. G r e e n (red.), The Encyclopedia of Judaism. Second edition, t. IV, Brill, Leiden, Boston 2005, kol. 2863-2871.

83 P.V.M. F l e s h e r, B. C h il to n, Targums, s. 257. 
W Targumie Kronik została zastosowana technika zgodna z egzegezą żydowską (por. b.Meg. 13b), która polega na tym, że konkretna postać była utożsamiana $\mathrm{z}$ inną postacią, często dużo bardziej znaczącą i zasłużoną. Z tego powodu dla tłumacza aramejskiego przedstawiona interpretacja nie stanowi problemu. Według niego kobieta ta wyciągnęła Mojżesza z wody, wychowała go i nadała mu 6 imion (imiona z TM 3 ojców i 3 synów), a znaczenie hebrajskich rdzeni każdego z nich stały się punktem wyjścia do sześciu krótkich komentarzy, które wychwalają przymioty i zasługi Mojżesza. Ponadto córka faraona zostaje prozelitką, a Mered utożsamiony z Kalebem bierze ją za żonę. Tg 1 i 2 Krn jest w tym miejscu bardzo podobny do b.Meg. 13a i LevR 1,1, które też przypisują Mojżeszowi właśnie w ten sposób dodatkowe cnoty i zalety. Podstawą całego rozszerzenia jest prawdopodobnie wyrażenie „córka faraona”, które przywodzi na myśl wyciągnięcie Mojżesza z wody i wychowanie go, a to z kolei prowadzi dalej do przypomnienia jego różnych zasług.

Technika ta została wykorzystana również w odniesieniu do innych postaci występujących w Pierwszej i Drugiej Księdze Kronik. ${ }^{84}$ Dla tłumacza, podobnie jak dla dawnych komentatorów, nie było żadnym problemem to, że między wymienionymi pokoleniami istniał dystans czasowy. ${ }^{85}$

Szczególnie rozbudowane tradycje hagadyczne występują w peanie na cześć Dawida, któremu targumista przypisuje m.in. wielką

84 Np. 1Krn 1,43: Balaam = Laban; 2,7: Karmi = Zimri; 2,19: Miriam = Efrata; 2,55: Jabes $=$ Otniel; 3,3: Egla $=$ Michal; 4,15: Merem $=$ Kaleb; 8,33: Abiel $=$ Ner; 23,16: Szebuel = Jonatan. Zamiarem tłumacza było podkreślenie przekazu, a do tego celu wybrał osoby zamiast przymiotników. Kiedy więc mówi, że Balaam to Laban, a Karmi to Zimri, stara się podkreślić, że złe jest zło, a nie wskazać złych bohaterów jako odrębne przykłady. Wszystkie te osoby zostają złączone w jedno, a powstały w ten sposób podmiot zbiorowy stanowi kwintesencję zła. Dokonując zrównania typu „, $\mathrm{x}=\mathrm{y}$ ”, bohaterowi „,x” targumista przypisuje zaletę, wadę lub przymiot bohatera ,y”, względnie wartość, którą można by z imienia tamtego wyprowadzić na gruncie lingwistycznym: w ten sposób bohater „x” staje się bardziej godny pochwały lub potępienia od swojego ,,pierwowzoru bazowego”.

85 Por. Mechilta do Wj 15,9 - „Tora nie trzyma się ściśle porządku chronologicznego dotyczącego tego co wcześniej i co później”. 
mądrość z powodu znajomości Prawa: „To są całkowite liczby wojowników, którzy byli z Dawidem, w oj ow n i k i e m, d o w ó d c ą obozu, zasiadającym na tronie sędziowskim, namaszczonym olejem świętym, z wszystkimi prorokami i mędrcami wokół siebie. Kiedy wyruszał do walki, otrzymywał pomoc z wysoka. Kiedy zasiadał, by dawać pouczenie w Prawie, do głowy przychodziły mu właściwe rozstrzygnięcia. Wybranyi skrupulatny, przystojny z wyglądu i nadobny w spojrzeniu, biegły w mądrości, rozsądny w radzie, potężny siłą, przywódca akademii, o miłym głosie, wybitny pieśniarz, zwierzchnik nad wszystkimi wojownikami, wyposażony w broń, noszący włócznię, na której zatknięty był znak oddziału obozu Judy, ruszający w drogę [pod w pływem] pouczenia [przez] ducha świętości, zwycięski w walce, a swoją włócznią za jednym razem p oł o ż ył trzystu mężów” (Tg 1Krn 11,11).

Poza czynami wojennymi w Tg 1Krn 11,11 znajduje się też wzmianka o zasiadaniu Dawida z prorokami. Targumista często wspomina o prorokach, którzy w tekście hebrajskim byli tak właśnie określani, ale także o innych, zwanych „mężami Bożymi”. W targumie byli to zawsze ,prorocy PANA” (Mojżesz w Tg 2Krn 23,14; Dawid w Tg 2Krn 8,14; Szemajasz w Tg 2Krn 11,2; anonim w Tg 2Krn 25,7). „Prorokiem” staje się również „Widzący” (Tg 2Krn 16,7.10), a jego „widzenie” to tak naprawdę ,proroctwo” (Tg 2Krn 32,32). Podobnie za każdym razem, kiedy tekst hebrajski mówi, że „słowo PANA było z...", targum dodaje kwalifikujący termin ,proroctwo” („słowo pror o c t wa s p r zed PANA [było] z..." - Tg 1Krn 17,3). ${ }^{86}$

W przywołanym wyżej fragmencie jest mowa także o tym, że Dawid ruszał do walki, ,[p od w pły we m]p ouczen i a [pr zez]

86 Szerzej zob. B. C hilt o n, Prophecy in the Targumim, w: t e n ż e (red.), Judaic Approaches to the Gospels, Scholars Press, Atlanta (GA) 1994, s. 245-270. 
d u cha ś w i ę to ś c i”, i dzięki temu odnosił zwycięstwa. ${ }^{87} \mathrm{~W}$ innym miejscu targum podaje, że Dawid wstawał, aby zgłębiać Prawo nawet w środku nocy (por. Tg 1Krn 20,5).

Charakterystyczne dla targumu jest to, że duch proroctwa zostaje ukazany jako jedno ze źródeł inspiracji grupy uczonych w Prawie: „przykryci byli duchem proroctwa” (Tg 1Krn 2,55). Duch proroctwa pomaga także Dawidowi sporządzić plan i rozkład świątyni (Tg 1Krn 28,12). Poddanie się duchowi proroctwa, pozwala poznać to, co normalnie byłoby zakryte. W tym kontekście za jeden z najważniejszych elementów ,proroctwa” można przyjąć zrozumienie Bożej mądrości, której odbiorcami byli uczeni w Prawie. W ten sposób targumista był zgodny z rabiniczną zasadą, stosowaną również w Talmudzie, że prorok ma za zadanie wyjaśniać i tłumaczyć naukę płynącą z objawienia, jakie Bóg dał Mojżeszowi.

Warto wspomnieć również o innych postaciach, które w Tekście Masoreckim nie odgrywały aż tak wielkiej roli jak Mojżesz i Dawid, a mimo to targumista akcentuje ich rangę i znaczenie, podkreślając ich wkład w życie i dzieło innych mężów Bożych. Postaci te są godne pochwały i naśladowania ze względu na swoją wiedzę i zrozumienie, np. Jabes, ,z nał się lepiej na Prawie niż jego bracia" (Tg 1Krn 4,9) ${ }^{88}$ i był założycielem akademii (Tg 1Krn 2,55), a Booz, mąż Rut, był nie tylko „,z w i e r z c h n i k i e m m ę drców uczelni w Betlejem, którzy angażowali się w zgłębianie słów [z] dni zamierzchłych”, ale tajego działalność przyczyniała się do, założe ni a świata ... i c ałkowitej odbudowy ruin domu Izraela... przez p osługę Tory" (Tg 1Krn 4,22-23). Benajasz, o którym dowiadujemy się z tekstu hebrajskiego, że miał być strażą przyboczną Dawida, w targumie ,został ustanowiony p r z y w ó d c ą a k a d e m i i i powierzeni mu zostali uczniowie"(W 1Krn 11,25),

87 Inny los spotkał Saula, który przegrał ostatnią walkę, bo „nie szukał pouczenia sprzed PANA przez Urim i Tummim" (Tg 1Krn 10,14). Podobnie stało się z Asą, a nawet Jozjaszem (Tg 2Krn 16,12; 35,23).

88 TM: „Był bardziej poważany niż jego bracia”. 
a kilka wierszy wcześniej otrzymuje zaszczytny tytuł „mistrza Tory” (w. 22). W innym miejscu Tekst Masorecki 1Krn 12,33 mówi o potomkach Issachara, że posiadali dar „,rozumienia czasów i wiedzieli, co Izrael powinien robić", tak w interpretacji targumisty byli oni „przywódcami Sanhedrynu, którzy postanowienia Tory wprowadzali w czyn".

\section{$* * *$}

Na podstawie przedstawionego przeglądu technik translatorskich oraz elementów egzegezy żydowskiej zastosowanych w Targumie Kronik można stwierdzić, że mamy do czynienia ze zjawiskiem targumizmu, dla którego punktem wyjścia, a zarazem punktem odniesienia, są hebrajskie księgi biblijne (głównie Księgi Samuela i Królewskie). Późne powstanie tego targumu potwierdza m.in. wykorzystanie już istniejących przekładów aramejskich, przede wszystkim Targum Jonatana do Proroków Wcześniejszych (Tg 1-2Sm i Tg 1-2Krl) i Targumy Pięcioksięgu, zwłaszcza Targum Pseudo-Jonatana oraz Targum Pism (Tg Rt i Tg Pnp). Harmonizacja ich przekazu w tym Targumie Kronik wskazuje, że został on napisany w czasie, kiedy wymienione targumy były już znane i poważane.

Należy podkreślić, że aramejski przekład Księgi Kronik jest świadectwem nie tylko przemian językowych, ale także kulturowych i religijnych, które znalazły wyraz w różnorodnych tendencjach interpretacyjnych. Tłumacz aramejski odpowiedział w ten sposób na najważniejsze potrzeby czytelnika, zapewniając mu teologicznie i doktrynalnie poprawną interpretację tekstu hebrajskiego. Ze względu na późną datację tego targumu, a także środowisko (bet midrasz - szkoła przygotowująca nowych znawców świętej Tradycji lub też prywatne studium świętych tekstów), występują w nim tradycje hagadyczne i midraszyckie, będące świadectwem rozwoju egzegezy żydowskiej.

Szeroka perspektywa historyczna Tg 1-2Krn, w połączeniu z częstym odwoływaniem się do innych targumów, pozwala tłumaczowi na rozwinięcie interakcji przeszłości z teraźniejszością, wyrażającej 
się w kontynuacji błogosławieństwa, które Bóg obiecał Izraelowi w kolejnych pokoleniach. W tym celu w swoich uzupełnieniach stawia nacisk na środki, służące realizacji tego zadania. Do najważniejszych należy tu zgłębianie i zachowywanie Prawa, które wyraża się także w zdobywaniu mądrości. Taką postawę prezentowały wcześniej najważniejsze postacie biblijne, ukazane przez tłumacza jako wzory do naśladowania. Dla targumisty ważna jest również pamięć o zasługach przodków, które zapewniły trwanie błogosławieństwa Boga nad Izraelem, szczególnie w kontekście podejmowania indywidualnych wyborów, mających wpływ na dalsze losy jednostek i całego narodu.

Anna KUŚMIREK

Słowa kluczowe: Pierwsza i Druga Księga Kronik; Pisma; Targum Kronik; przekład aramejski

Keywords: 1-2 Book of Chronicles; Writings; Targum Chronicles; aramaic translation

\section{The Features of Targumism in the Aramaic Translation of the First and the Second Books of Chronicles Summary}

The main objective of the article is to show the features of the Aramaic translation of the First and the Second Books of Chronicles which belongs to the late Targums. The work presents the main data related to the authority, date and origin of the Targum and its manuscripts and the review of major translation techniques and the method of rabbinic interpretation, which are all important elements of the targumism. Linguistic changes, as well as cultural and religious ones, conditioned by various processes that occurred in the community of believers in YHWH over the centuries, were reflected in separate interpretative tendencies. 


\section{Bibliografia}

A $1 \mathrm{e} x$ a $\mathrm{d}$ e r P. S., Targum, Targumim, w: Fr e e d m a n D. N. (red.), The Anchor Yale Bible Dictionary, t. 6, Doubleday, New York 1992, s. 321-331.

B a r d s k i K., Światynia Salomona w Targumie do Pieśni nad Pieśniami 3,7 $-5,1$, Collectanea Theologica 2/2000, s. 79-92.

B a rd sk i K., Niewola babilońska winterpretacji Targumu do Pieśni nad Pieśniami 5,2 - 6,17, Studia Lovicensia 3/2001, s. 25-39.

B a rd s k i K., Eschatologia mesjańska w Targumie do Pieśni nad Pieśniami 7,12-8,14, w: Ch ros tow sk i W. (red.), Duch i Oblubienica mówia: „Przyjdz”. Ksiegga Pamiątkowa dla Ojca Profesora Augustyna Jankowskiego OSB $w$ 85. rocznice urodzin, Vocatio, Warszawa 2001, s. 47-58.

B a r a n a k M., Motyw miasta w Księdze Pieśni nad Pieśniami i jego targumiczna interpretacja, Scriptura Biblica et Orientalia 3/2011, s. 209-233.

B a r n i a M., Zjawisko targumizacji na podstawie Targumu do Pieśni nad Pieśniami. Krytyczna edycja tekstu z manuskryptu M 1106 z analiza egzegetyczno-hermeneutyczna i tłumaczeniem, Dom Wydawniczy ELIPSA, Warszawa 2013.

$\mathrm{C}$ h e s t e r A., Divine Revelation and Divine Titles in the Pentateuchal Targumim, Texte und Studien zum Antiken Judentum 14, J.C.B. Mohr, Tübingen 1986.

C h i 1 t o n B. (red.), Judaic Approaches to the Gospels, Scholars Press, Atlanta (GA) 1994.

C h u r g i n P., The Targum to Hagiographa [hebr.], Horeb, New York 1945.

Chrostowski W., M. Baraniak, „Zjawisko targumizacji na podstawie Targumu do Pieśni nad Pieśniami. Krytyczna edycja tekstu z manuskryptu M 1106 z analiza egzegetyczno-hermeneutyczna i ttumaczeniem", Dom Wydawniczy ELIPSA, Warszawa 2013 (rec.), Collectanea Theologica 83(2013) nr 4, s. 232-238.

F le sh e r P.V.M., Ch ilt o n B., Targums: A Critical Introduction, Baylor University Press, Waco (TX) 2011.

$\mathrm{H}$ a $\mathrm{m}$ i 1 t o n V.P., Handbook on the Historical Books, Baker Academic, Grand Rapids (MI) 2001.

K a 1 i m i I., History of Interpretation: The Book of Chronicles in Jewish Tradition from Daniel to Spinoza, RB 105/1998, s. 5-41.

$\mathrm{K}$ a 1 i $\mathrm{m}$ i I., The Retelling of Chronicles in Jewish Tradition and Literature: A Historical Journey, Eisenbrauns, Winona Lake (IN) 2009.

K a s h e r R., The Aramaic Targumim and Their Sitz im Leben, World Congress of Jewish Studies 9, Panel Sessions: Bible Studies and Ancient Near East, Jerusalem 1988, s. 75-85. 
K l e i n R.W., Chronicles, Book of 1-2, w: Fre e d m a n D.N. (red.), The Anchor Yale Bible Dictionary, t. 1, Doubleday, New York 1992, s. 992-1001.

K u ś m i r e k A., Światynia jerozolimska w targumach, Collectanea Theologica 79(2009) nr 2, s. 65-76.

$\mathrm{K}$ uś m i r e k A, Twój naród będzie moim narodem, twój Bóg będzie moim Bogiem - wyznanie Rut w interpretacji targumu (Rt 1,16-17), w: L i n k e W. (red.), Trud w Panu nie jest daremny (por. 1Kor 15,58). Studia ofiarowane Księdzu Profesorowi Doktorowi Habilitowanemu Janowi Zatęskiemu w 70. rocznice urodzin, Wydawnictwo Ojców Franciszkanów, Niepokalanów 2010, s. 309-324.

K uś m i r e k A., Księga Nahuma w tradycji targumicznej, Collectanea Theologica 81(2011) nr 4, s. 101-120.

Kuśmi re k A., Aramejska wersja Księgi Amosa, Collectanea Theologica 85 (2015) nr 4, s. 177-195.

K u ś m i r e k A., Księga Rodzaju 1-11 w targumach palestyńskich, Collectanea Theologica 83(2017) nr 4, s. 75-104.

K u śm i r e k A., Błogosławieństwo Jakuba (Rdz 49,1-28) w interpretacji targumicznej, Collectanea Theologica 88(2018) nr 4, s. 163-190.

L a ga rde P., Hagiographa Chaldaice, Leipzig 1873; reprint Zeller, Osnabrück 1967.

L e D é a u t R., R o be r t J., Targum des Chroniques (Cod. Vat. urb. Ebr. 1), t. I-II, Analecta Biblica 51, Pontifical Biblical Institute, Rome 1971.

L e v i n e E., The Aramaic Version of the Bible. Contents and Context, Walter de Gruyter, Berlin 1988.

M c I v o r J.S., The Targum Chronicles. Translated, with Introduction, Apparatus, and Notes, w: Cathcart K., Maher M., McNamara, M. (red.), The Aramaic Bible: The Targum of Ruth and The Targum Chronicles, t. II, The Liturgical Press, Collegeville (MN) 1994.

Ne usner J., Zekhut, w: Ne u sner J., Avery-Peck A.J., Green W.S. (red.), The Encyclopedia of Judaism. Second edition, t. IV, Brill, Leiden, Boston 2005, kol. 2863-2871.

R ibera-Florit J., Doctrinal Peculiarities of TgChr, w: Ne u s n e r J., A very-Peck A.J., (red.), Encyclopedia of Midrash, Brill, Leiden 2005, s. 170-173.

R o s e n b e rg M., K o h le r K., Das Targum zur Chronik, Jüdische Zeitschrift für Wissenschaft und Leben 8/1870, s. 274-276.

S a nder s J. A., Canon: Hebrew Bible, w: Free d man D.N. (red.), The Anchor Yale Bible Dictionary, t. 1, Doubleday, New York 1992, s. 832-851. 
S e $1 \mathrm{~m}$ a $\mathrm{n}$ M.J., 1 Chronicles: An Introduction and Commentary, Tyndale Old Testament Commentaries 10, InterVarsity Press, Downers Grove (IL) 1994. $\mathrm{S} \mathrm{m}$ o l a r L., A b e r b a c h M., Studies in Targum Jonathan to the Prophets, Ktav Pub \& Distributors, New York 1983.

S p e r b e r A., The Bible in Aramaic, IVA, Leiden 1968.

Wrób e 1 M. (tłum. i oprac.), Biblia Aramejska. Targum Neofiti 1. Księga Rodzaju, t. 1, Wydawnictwo Gaudium, Lublin 2014.

W ró b e 1 M. (tłum. i oprac.), Biblia Aramejska Targum Neofiti 1. Księga Wyjścia, t. 2. Wydawnictwo Gaudium, Lublin 2017.

Wró b e 1 M. S., Wprowadzenie do Biblii Aramejskiej, Wydawnictwo Gaudium, Lublin 2017. 